\title{
Motor neurone disease and multiple sclerosis among immigrants to Britain
}

\author{
GEOFFREY DEAN, ROSALEEN BRADY, AND HILDA MCLOUGHLIN \\ From the Medico-Social Research Board, Dublin
}

\author{
MARTA ELIAN
}

From St Bartholomew's Hospital, London

\author{
ABRAHAM M. ADELSTEIN \\ From the Office of Population Censuses and Surveys, London
}

SUMMARY Hospital discharge rates for various immigrant groups resident in Greater London and the West Midlands were studied to compare the incidence of two diseases of the nervous system-motor neurone disease (MND) and multiple sclerosis (MS). For both these conditions immigrants from Europe, Ireland, America and from the old commonwealth countries of Canada, Australia, and New Zealand had discharge rates that were similar to those for people born in the United Kingdom. In contrast, immigrants from the new commonwealth countries of Asia, Africa, America (including the West Indies), and Europe (Gibraltar, Malta, and Gozo) had a greatly reduced risk of MS but a very similar risk of MND compared with those born in the United Kingdom. MS but not MND was rare among immigrants of Asian or African ethnic origin and uncommon among immigrants from the West Indies. Deaths attributed to MS and MND have also been studied. During a three-year period there were no deaths reported for MS among immigrants of Asian and African ethnic origin and 14 were expected. There were two deaths from MND among these immigrants and five were expected. Among the immigrants from the West Indies two deaths were attributed to MS and 13 were expected, and there were three deaths attributed to MND and four were expected. The contrast between MND and MS in hospital morbidity and mortality confirms that MS among immigrants to Britain is rare in those of Asian and African ethnic origin.

Few immigrants in Greater London from the new commonwealth countries of Asia, Africa, America (including the West Indies), and Europe (Gibraltar, Malta, and Gozo) were discharged from hospital with a diagnosis of multiple sclerosis (MS) compared with those born in the United Kingdom or with immigrants from Europe, Ireland, America, or the old commonwealth countries (Dean et al., 1976). MS was rare among those of Asian of African ethnic stock. Discharges from hospital of those with another neurological disease, motor neurone disease (MND), which causes neurological symptoms not unlike MS, have been analysed and compared with those discharged from hospital with MS in Greater London and the West Midlands; deaths attributed to MS and MND among immigrant groups in England have also been studied.

\section{Method}

At the 1971 census there were 1121440 immigrants who were born in the new commonwealth countries and $60 \%$ of these were resident in Greater London, the West Midlands, Bradford, and Leicester. In the study on the hospital admissions (1960-72) among residents in Greater London the $196610 \%$ sample census was used for the population at risk (Dean et al., 1976). In the West Midland conurbation populations at risk by sex and age group were obtained from the 1971 census to match the period over which we studied hospital records-namely, 1967-74.

There are considerable variations in the age distribution of different groups of immigrants. For instance, the immigrants from the new commonwealth countries are, on the whole, younger than 
those from Europe. In Greater London the United Kingdom-born population of Greater London was, therefore, used as the standard and the age-specific expected number of patients with MS for the different immigrant groups was calculated using the age distribution of those born in the United Kingdom and of the immigrant populations at risk. Similarly in the West Midland conurbation the United Kingdom-born population of the conurbation was used as the standard and the age-specific expected number of patients with MS in the different immigrant groups was calculated.

The enumeration of immigrant communities in a census may present special difficulties, owing in particular to language problems and housing conditions. The Office of Population Censuses and Surveys, Census Division, has, therefore, carried out three special checks on the coverage in the 1971 census of persons born in the new commonwealth, in addition to the usual general coverage checks and post-enumeration surveys. None of these checks suggests that there was significant under-enumeration among new commonwealth immigrants. Thus, if there was any error in the census it was underenumeration but this was extremely small (Office of Population Censuses and Surveys, 1975).

In the West Midlands, Hospital Activity Analysis computer printouts were obtained for all hospital admissions for MS and MND for the eight years from 1967 to 1974. In addition the diagnostic indices, where such an index was kept-for instance, at the teaching hospitals and the Midland Centre for
Neurosurgery and Neurology-were studied. The 8 case folders of the patients with MS and MND were perused. The West Midlands consists of a central urban conurbation based on Birmingham (popula- ? tion 2374070 (1971)) and the remainder of the West $\overrightarrow{\vec{A}}$ Midlands outside this area (population 2535 280). The diagnosis of probable MS and MND made by the consultant neurologists was accepted in this study and case summaries of all immigrants with these two conditions were obtained.

In Greater London the study was undertaken both कै of all admissions to hospital during the 13-year $\overrightarrow{0}$ period, 1960-72, and of first admissions (Dean et al., $\vec{\overrightarrow{ }}$ 1976). In the West Midlands, unlike London, many $\vec{\omega}$ hospitals did not have a diagnostic index which $\frac{\rho}{\bar{D}}$ would have made it possible to distinguish whether $\stackrel{\odot}{)}$ an admission was a first admission or a subsequent one. Age-standardised expected numbers, based on $\vec{\omega}$ the rates of those born in the United Kingdom, were $\vec{A}$ therefore calculated for all persons admitted with $\doteq$ either disease in the West Midland conurbation 을 during the period 1967-74, whether they had beef admitted before 1967 or not. The case record $\mathcal{D}_{\mathbb{D}}$ of immigrants who were resident in the remaindef $\frac{\mathbb{0}}{\overrightarrow{0}}$ of the West Midlands outside the West Midlane $\frac{D}{3}$ conurbation or who lived in Bradford and Leiceste were also studied, but the expected number of admissions was not calculated for these areas.

\section{Results and comments}

Table 1 shows the actual and expected numbers of

Table 1 MS: Persons admitted to hospital. (Expected number in brackets)

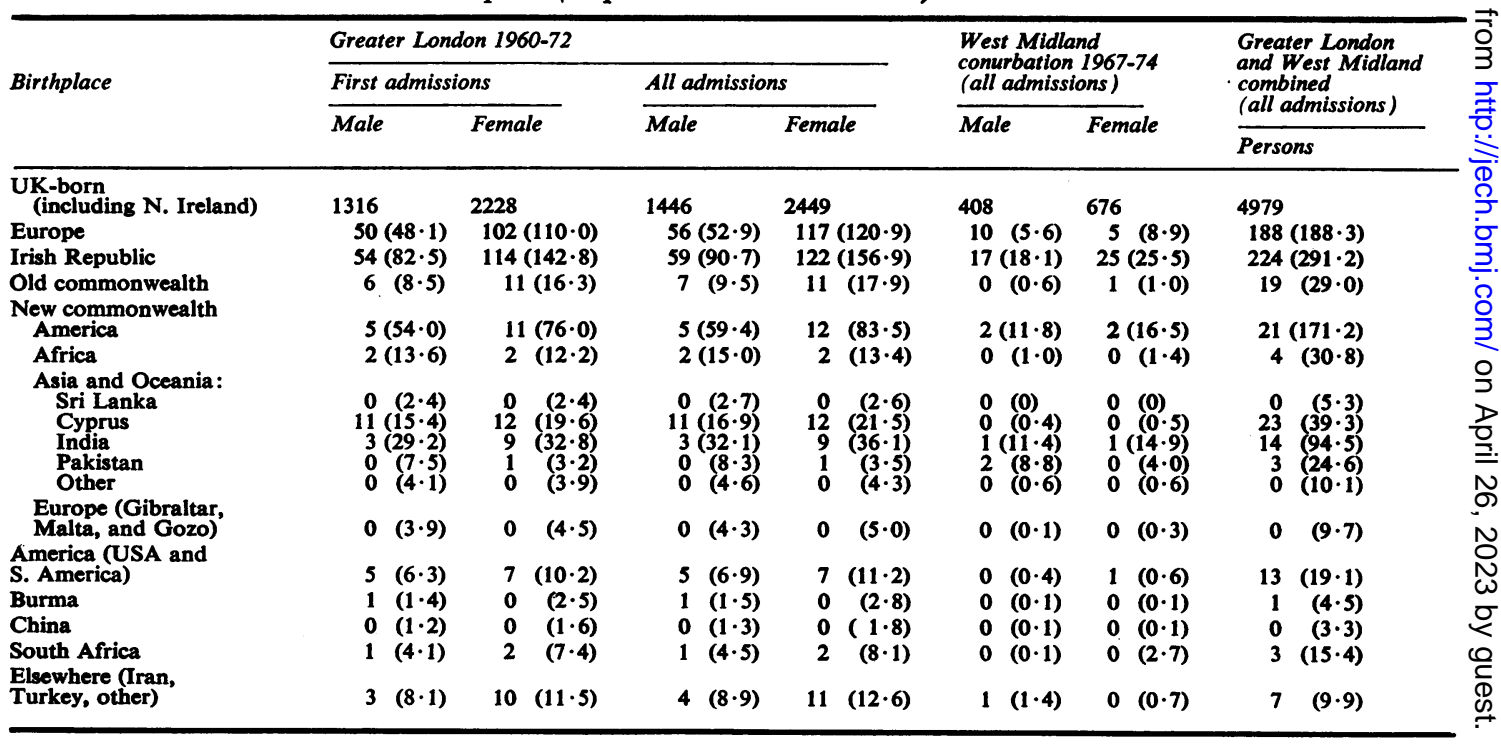


immigrants with multiple sclerosis resident in Greater London in 1960-72, both first admissions and all admissions, all MS admissions for residents in the West Midland conurbation 1967-74, and all admissions for the two areas combined.

In the West Midland conurbation the hospitalised prevalence of MS for patients who immigrated from Europe and from the old commonwealth countries is not significantly different from the expected number based on the rates among the United Kingdom-born. In Greater London (1960-72) there were fewer cases among immigrants from the Irish Republic than expected but this was not so in the West Midland conurbation (1967-74), 42 MS patients, 43.6 expected. In Greater London it was only possible to find the birthplace by studying the case notes and by making further inquiries from the patient's general practitioner, whereas in the West Midlands the birthplace had usually been noted on the Hospital Activity Analysis form at the time of admission. This suggests that a few patients with MS born in the Irish Republic resident in Greater London may have been inadvertently included among the United Kingdom-born and that there is very little difference in the rates between those born in the Irish Republic and those born in the United Kingdom.

There were very few MS patients among the immigrants from the new commonwealth countries. In the West Midlands there were four born in new commonwealth Asian countries $(41 \cdot 2$ expected). Two of these were born in India of European ethnic origin and two were born in Pakistan of Pakistani ethnic origin. In addition, there was one patient with possible MS from Pakistan who is not included.
There were no MS patients among the immigrants from new commonwealth Africa ( $2 \cdot 4$ expected). Among those born in new commonwealth America, including the West Indies, there were four patients, all Jamaican West Indians ( $28 \cdot 3$ expected), a very similar proportion to the 16 MS patients $(142 \cdot 9$ expected) from new commonwealth America in Greater London. The study of multiple sclerosis in the West Midland conurbation therefore confirmed the low hospitalised prevalence for MS among the new commonwealth immigrants already found among residents in Greater London.

\section{Motor neurone disease}

Among immigrants from Europe and the USSR and from the old commonwealth countries the numbers of hospitalised patients with MND in Greater London and the West Midland conurbation combined, 28 and 3 respectively, were similar to the expected numbers (28.5 and 3.9), Table 2 . Among immigrants from the Irish Republic there were fewer than expected patients with MND (26 and 37.6 expected). Among the immigrants from the new commonwealth countries of America, Africa, and Europe there was hardly any difference between the actual and expected number of hospitalised patients for MND compared with the very large difference for MS. Among immigrants from new commonwealth Asia there were fewer than expected patients with MND (6 and $16 \cdot 7$ expected). Two of the six were born in Cyprus ( $3 \cdot 4$ expected), 3 in India (10.1 expected), and 1 in Pakistan ( $2 \cdot 5$ expected). Three of the four patients from India and Pakistan were of Indian or Pakistani ethnic origin. MND may

Table 2 MND: All admissions to hospital. (Expected number in brackets)

\begin{tabular}{|c|c|c|c|c|c|}
\hline \multirow{2}{*}{ Birthplace } & \multicolumn{2}{|c|}{ Greater London 1960-72 } & \multicolumn{2}{|c|}{$\begin{array}{l}\text { West Midland conurbation } \\
1967-74\end{array}$} & \multirow{2}{*}{$\begin{array}{l}\text { Greater London } \\
\text { and West Midland } \\
\text { combined } \\
\text { Persons }\end{array}$} \\
\hline & Male & Female & Male & Female & \\
\hline UK, including N. Ireland & 429 & 273 & 168 & 84 & 954 \\
\hline Europe and USSR & $17(15 \cdot 2)$ & $9(11 \cdot 1)$ & $2(1 \cdot 9)$ & $0(0 \cdot 5)$ & $28(28 \cdot 5)$ \\
\hline Irish Republic & $17(19 \cdot 3)$ & $4(11 \cdot 7)$ & $4(4 \cdot 9)$ & $1(1 \cdot 7)$ & $26(37 \cdot 6)$ \\
\hline $\begin{array}{l}\text { Old commonwealth (Australia, Canada, } \\
\text { and New Zealand) } \\
\text { New commonwealth }\end{array}$ & $0(1 \cdot 7)$ & $3(1 \cdot 1)$ & $0(0 \cdot 2)$ & $0(0 \cdot 9)$ & $3(3 \cdot 9)$ \\
\hline $\begin{array}{l}\text { America } \\
\text { Africa } \\
\text { Asia and Oceania: } \\
\text { Sri Lanka } \\
\text { Cyprus } \\
\text { India } \\
\text { Pakistan } \\
\text { Other } \\
\text { Europe (Gibraltar, Malta, and Gozo) }\end{array}$ & $\begin{array}{rr}4 & (6 \cdot 9) \\
1 & (0 \cdot 9) \\
4 & (8 \cdot 6) \\
-0 & (0) \\
-1 & (2 \cdot 3) \\
-3 & (4 \cdot 9) \\
-0 & (0 \cdot 9) \\
-0 & (0 \cdot 5) \\
0 & (0 \cdot 8)\end{array}$ & $\begin{array}{rr}3 & (3 \cdot 3) \\
0 & (0 \cdot 4) \\
1 & (3 \cdot 7) \\
-0 & (0) \\
-1 & (1 \cdot 1) \\
-0 & (2 \cdot 3) \\
-0 & (0 \cdot 1) \\
-0 & (0 \cdot 2) \\
1 & (0 \cdot 4)\end{array}$ & $\begin{array}{rl} & 2(2 \cdot 0) \\
1(0 \cdot 1) & 1(3 \cdot 7) \\
1 & 0(0) \\
-0(0) \\
-0(2 \cdot 3) \\
-1(1 \cdot 4) \\
-0(0) \\
0(0)\end{array}$ & $\begin{aligned} 1(0 \cdot 5) \\
0(0 \cdot 0) \\
0(0 \cdot 7) \\
-0(0) \\
-0(0) \\
-0(0 \cdot 6) \\
-0(0 \cdot 1) \\
-0(0) \\
0(0)\end{aligned}$ & $\begin{array}{r}10(12 \cdot 7) \\
2(1 \cdot 4) \\
6(16 \cdot 7) \\
-0(0) \\
-2(3 \cdot 4) \\
-3(10 \cdot 1) \\
-1(2 \cdot 5) \\
-0(0 \cdot 7) \\
1(1 \cdot 2)\end{array}$ \\
\hline America (USA and S. America) & $1(1 \cdot 1)$ & $1(0 \cdot 7)$ & $0(0 \cdot 1)$ & $1(0 \cdot 1)$ & $3(2 \cdot 0)$ \\
\hline Burma & $0(0 \cdot 2)$ & $0(0 \cdot 2)$ & $0(0)$ & $0(0)$ & $0(0.4)$ \\
\hline China & $0(0 \cdot 2)$ & $0(0 \cdot 1)$ & $0(0)$ & $0(0)$ & $0(0 \cdot 3)$ \\
\hline South Africa & $1(0.8)$ & $1(0.6)$ & $0(0)$ & $0(0)$ & $2(1 \cdot 2)$ \\
\hline Elsewhere (Iran, Turkey, other) & $1(1 \cdot 2)$ & $0(0.8)$ & $0(0 \cdot 2)$ & $0(0)$ & $1(2 \cdot 2)$ \\
\hline
\end{tabular}


Table 3 Immigrants from countries with a low MS rate resident in Greater London and West Midland conurbation

\begin{tabular}{|c|c|c|c|c|}
\hline \multirow{2}{*}{ Country } & \multicolumn{2}{|c|}{ Multiple sclerosis } & \multicolumn{2}{|c|}{ Motor neurone disease } \\
\hline & Actual & Expected & Actual & Expected \\
\hline New commonwealth America & 21 & $171 \cdot 2$ & 10 & $12 \cdot 7$ \\
\hline $\begin{array}{l}\text { New commonwealth Africa } \\
\text { African and Asian ethnic } \\
\text { European (or partly) ethnic }\end{array}$ & $\begin{array}{r}4 \\
-3 \\
-1\end{array}$ & $30 \cdot 8$ & $\begin{array}{l}2 \\
-2 \\
-0\end{array}$ & 1.4 \\
\hline $\begin{array}{l}\text { New commonwealth Asia (except Cyprus) } \\
\text { India } \\
\text { Indian ethnic } \\
\text { Other ethnic }\end{array}$ & $\begin{array}{r}17-14 \\
2 \\
12\end{array}$ & $\stackrel{134 \cdot 5}{-94 \cdot 5}$ & $\begin{array}{r}4 \\
-3 \\
2 \\
1\end{array}$ & $\stackrel{13 \cdot 3}{-10 \cdot 1}$ \\
\hline $\begin{array}{l}\text { Pakistan } \\
\text { Pakistan ethnic } \\
\text { Other ethnic }\end{array}$ & $\begin{array}{r}-3 \\
2 \\
1\end{array}$ & $-24 \cdot 6$ & $\begin{array}{r}-1 \\
1 \\
0\end{array}$ & $-2 \cdot 5$ \\
\hline Remainder of Asia & -0 & $-10 \cdot 1$ & -0 & $-0 \cdot 7$ \\
\hline $\begin{array}{l}\text { New commonwealth Europe (Gibraltar, Malta, } \\
\text { and Gozo) }\end{array}$ & 0 & $9 \cdot 7$ & 1 & $1 \cdot 2$ \\
\hline $\begin{array}{l}\text { Burma and China } \\
\text { Other ethnic }\end{array}$ & $1-1$ & $7 \cdot 8$ & $\mathbf{0}$ & 0.7 \\
\hline $\begin{array}{l}\text { South Africa } \\
\text { White }\end{array}$ & $4^{3}-3$ & $\begin{array}{r}15 \cdot 4 \\
369 \cdot 4\end{array}$ & $1^{2}-2$ & $\begin{array}{r}1 \cdot 2 \\
30 \cdot 5\end{array}$ \\
\hline Ratio of expected to actual & & & & \\
\hline
\end{tabular}

be less common, or less commonly diagnosed, among Indians and Pakistanis than among Europeans. The ratio of actual to expected numbers of patients with MS is $1: 8$ from the new commonwealth countries combined and the rest of Asia and South Africa. In contrast, the ratio from these countries for MND is $1: 1 \cdot 5$, Table 3 . The small difference between the actual and expected number with MND is strong confirmatory evidence that the very low risk of developing MS among immigrants from the new commonwealth countries and the rest of Asia, particularly among those of Asian and African ethnic origin, is real and is not due to a low hospitalisation rate among these immigrants or to the failure of seriously crippled persons to migrate. There were two immigrants from South Africa with MND (1.2 expected).

\section{Other areas}

A search was made for new commonwealth immigrants in the Hospital Activity Analysis and in the hospital records for those resident in the rest of the West Midlands (1967-74), including Coventry, and in two other cities with high immigrant populations, Bradford and Leicester (1960-72). The expected number for these areas was not calculated as coverage was not complete. In the rest of the West Midlands no patient was found of Indian, Pakistani, or African ethnic stock; however, one MS patient of West Indian ethnic stock was found resident in Coventry. In Bradford three male Pakistanis and one West Indian MS patient were found and in the Leicester records two MS patients of West Indian ethnic origin were found.

\section{Age at immigration}

The age at immigration and age at onset of MS shown in Table 4 for the patients of Indian, Parse Pakistani, Asian (two born in Africa), or Africap origin. Similar information is shown in Table 5 fo the patients of West Indian ethnic stock. There was also one immigrant from the West Indies whose. parents had both been born in England and anothe? with one parent born there.

\section{Deaths from MS and MND}

Since April 1969 the place of birth has been recorded on death certificates in England and Wales. It has

Table 4 Age at immigration and age at onset of MS in patients of Indian, Parsee, Pakistani, African-Asian, and African ethnic origin resident in Greater London, West Midlands, Bradford, and Leicester

\begin{tabular}{|c|c|c|}
\hline Ethnic origin & $\begin{array}{l}\text { Age at } \\
\text { immigration } \\
\text { (years) }\end{array}$ & $\begin{array}{l}\text { Age at } \\
\text { onset of MS } \\
\text { (years) }\end{array}$ \\
\hline $\begin{array}{l}\text { Indian } \\
1 \text { female } \\
1 \text { male }\end{array}$ & $\begin{array}{l}32 \\
19\end{array}$ & $\begin{array}{l}33 \\
22\end{array}$ \\
\hline $\begin{array}{l}\text { Parsee } \\
1 \text { female }\end{array}$ & 23 & 26 \\
\hline $\begin{array}{l}\text { Pakistani } \\
4 \text { male }\end{array}$ & $\begin{array}{l}16 \\
26 \\
27\end{array}$ & $\begin{array}{l}28 \\
37 \\
21 \\
40\end{array}$ \\
\hline $\begin{array}{l}\text { New commonwealth African-Asian } \\
2 \text { male }\end{array}$ & $\begin{array}{l}39 \\
17\end{array}$ & $\begin{array}{l}34 * \\
21\end{array}$ \\
\hline $\begin{array}{l}\text { African } \\
1 \text { female }\end{array}$ & 21 & 27 \\
\hline
\end{tabular}


Table 5 Patients with MS from new commonwealth America of West Indian ethnic origin resident in Greater London, West Midlands, Bradford, and Leicester

\begin{tabular}{lll}
\hline Onset of $M S$ & $\begin{array}{l}\text { Age at } \\
\text { immigration } \\
\text { (years) }\end{array}$ & $\begin{array}{l}\text { Age at } \\
\text { onset of } M S \\
\text { (years) }\end{array}$ \\
\hline $\begin{array}{lll}\text { Before immigration } \\
2 \text { female }\end{array}$ & 21 & 14 \\
1 male & 39 & 37 \\
Mean age & 46 & 44 \\
After immigration & $35 \cdot 3$ & $31 \cdot 6$ \\
11 female & 17 & 34 \\
& 30 & 40 \\
& 25 & 32 \\
& 20 & 23 \\
& 43 & 46 \\
& 31 & 37 \\
& 20 & 27 \\
male & 27 & 31 \\
& 20 & 27 \\
Total mean age & 18 & 30 \\
Mean age & 20 & 33 \\
\hline
\end{tabular}

There were a further two patients whose forebears were of European stock and in three patients the age at immigration was unknown.

already been described how among the MS and MND hospitalised patients the expected number of patients was calculated according to the age distribution of the census population of immigrants. Census figures by place of birth and parents' place of birth do not allow an accurate analysis by 'ethnic' origin. In order to determine the ethnic origin of immigrants from India, Pakistan, and Africa the expected number of deaths was calculated for
1970-72 (age-standardised) based on all deaths of the immigrant population at risk and according to whether the names appeared to be English or Indian, Pakistani or African.

Table 6 shows the observed and expected number of deaths from MS and MND, (a) for the period 1969 (April) to 1973 by population at risk, (b) for the period 1970-72 based on the ethnic group as judged by name, calculated as proportion of all deaths.

Among the immigrants from Europe, including the USSR, and from Ireland (both Northern Ireland and the Republic), the actual number of MS and MND deaths differs little from the expected number. Among the deaths for immigrants from the Indian subcontinent none was reported as being caused by MS in those of Asian ethnic origin, although the expected number was $11 \cdot 6$. There were two deaths among Indians of Asian ethnic origin ascribed to MND (4.6 expected). There were six deaths from MS among persons of other ethnic origin, most of these being of Anglo/Indian or European ethnic origin $(9 \cdot 8$ expected). There were also five deaths ascribed to MND among this group (6.7 expected). There were no deaths from MS or MND among the immigrants from new commonwealth Africa of African or Asian ethnic origin, although 2.6 were expected from MS and 0.7 from MND.

If the immigrants of Asian and African ethnic origin are taken together there were no reported deaths in the three-year period ascribed to MS (14.2 expected) and there were two deaths attributed to MND (5.3 expected). While there were fewer death

Table 6a MS and MND deaths among immigrants, England and Wales 1969-73. Expected deaths based on age-standardised populations

\begin{tabular}{|c|c|c|c|c|}
\hline \multirow{2}{*}{ Place of birth } & \multicolumn{2}{|c|}{ Multiple sclerosis } & \multicolumn{2}{|c|}{ Motor neurone disease } \\
\hline & Actual & Expected & Actual & Expected \\
\hline $\begin{array}{l}\text { Europe (including USSR) } \\
\text { Ireland } \\
\text { India and Pakistan } \\
\text { New commonwealth Africa } \\
\text { West Indies }\end{array}$ & $\begin{array}{r}67 \\
84 \\
11 \\
0 \\
3\end{array}$ & $\begin{array}{r}69 \cdot 2 \\
94 \cdot 2 \\
29 \cdot 9 \\
4 \cdot 3 \\
18 \cdot 1\end{array}$ & $\begin{array}{r}39 \\
59 \\
17 \\
1 \\
6\end{array}$ & $\begin{array}{r}44 \cdot 3 \\
58 \cdot 7 \\
16 \cdot 6 \\
1 \cdot 5 \\
6 \cdot 7\end{array}$ \\
\hline
\end{tabular}

Table 6b MS and MND deaths among immigrants, England and Wales, 1970-72, by ethnicity expected on proportional rates. Expected deaths based on proportions of all deaths (age standardised)

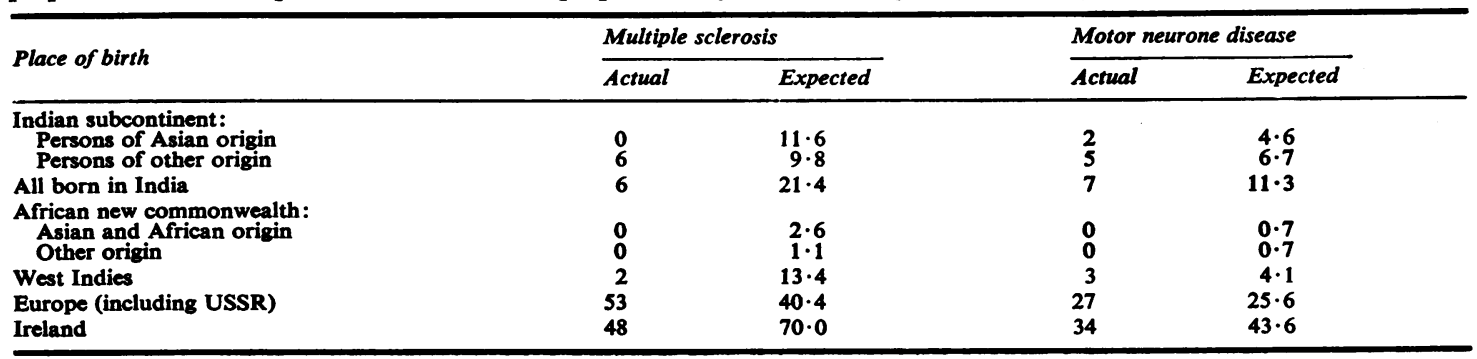


from MND among those of Asian and African ethnic origin than expected $(2$ to $5 \cdot 3)$, there was not the large difference that was present with MS $(0$ to 14.2).

Among the immigrants from the West Indies there were two deaths attributed to MS (13.4 expected) and, in contrast, there were three deaths from MND $(4 \cdot 1$ expected).

The absence of any deaths attributed to MS in those of Indian, Pakistani, and African ethnic origin and the fact that deaths were only one-seventh of those expected in those from the West Indies, confirms that MS is rare in immigrants of Indian, Pakistani, and African ethnic origin. Among the immigrants from the West Indies the ratio of expected to actual number of deaths $(7: 1)$ confirms the high ratio among the hospitalised patients $(8: 1)$.

\section{Discussion}

MND is as common among the various immigrant groups resident in England and Wales as in those born in the United Kingdom, except that there were fewer hospital discharges and deaths from MND than expected in those of Indian and Pakistani ethnic origin although the disease is not uncommon among them. The apparently lower risk of MND among Indians and Pakistanis may be an important clue to the aetiology of the disease (Lancet, 1977). In contrast MS is rare in immigrants resident in England and Wales who were born of Indian, Pakistani, or African ethnic origin. It is slightly more common among the people of mixed race who have immigrated to England and Wales from new commonwealth America (including the West Indies). Immigrants from new commonwealth Asia and Africa who are of White stock or of mixed racial origin have a much higher incidence of MS than those of Asian and African ethnic origin. Immigrants from South Africa are an interesting group because in South Africa MS is only one-quarter as common in the English-speaking White South Africans and only one-eleventh as common in the Afrikaansspeaking White South Africans as among the United Kingdom-born (Dean, 1967a). In Greater London and the West Midlands conurbation there were $15 \cdot 4$ cases of MS expected among immigrants from South Africa whereas only three cases were recorded, less than one-fifth of the expected cases.

The low prevalence of MS in South Africa in the White African-born, particularly the Afrikaansspeaking White South Africans, is strong evidence that an environmental factor is important in the causation of multiple sclerosis. In contrast, the very small number of cases of MS among immigrants to
England and Wales of Indian, Pakistani or African ethnic origin, and the complete absence so far of any reported patients with MS among South Africa's 17 million Black people does raise the question of racial or genetic susceptibility to multiple sclerosis. Are Asians and Africans genetically less susceptible to MS than Europeans and people of semitic stock, or does their environment protect them?

In this study there were no MS patients born in Malta and Gozo, although $9 \cdot 7$ were expected. This is of great interest because among immigrants from Cyprus there were 23 when $39 \cdot 3$ were expected, 17 were Greek Cypriots and six were Turkish Cypriots. Among the immigrants from Cyprus resident in Greater London and the West Midland conurbation the number and age distribution of Greek Cypriots and of Turkish Cypriots separately is not available. However, in Greater London there were two MS patients born in Turkey out of 3690 immigrants from Turkey, which suggests that immigrants of Turkish origin do not have a greatly different risk of developing MS than those of Greek Cypriot origin.0 The only other European country with a significantlye $\vec{P}$ lower risk of MS than expected is Spain (Dean $e^{\$} \mathbb{D}$ al., 1976). The European Economic Community is now sponsoring a study of the prevalence of MS ing the islands of Malta and Sicily.

MS would appear to be a disease dependent of $\overrightarrow{0}$ the interaction of genetic and environmentat. factors. The low prevalence of MS among White South Africans is strong evidence that an environ:mental factor is important, although the very low risk among Asians and Africans, and the known family tendency towards MS, would suggest that there is also a genetic factor. The situation in MS could be compared perhaps to rheumatic fever in which there is both a genetic predisposition and an environmental factor, a streptococcal infection, which precipitates the disease in the predisposed. While little can be done at present about any genetic predisposition that may be present the great hope for the future lies in dealing with the environmental factor or factors.

The epidemiology of MS resembles that of adult poliomyelitis before the introduction of the Salk and Sabin vaccines (Poskanzer et al., 1963). Both MS and adult poliomyelitis were common in countries with a high standard of hygiene. Immigrants from high risk areas such as northern Europe to low risk areas such as South Africa and Israel kept their high risk of developing MS, or formerly of adult poliomyelitis, unless they had immigrated in childhood (Dean and Kurtzke, 1971; Leibowitz and Alter, 1973; Dean, 1967b). Conversely, those who 6 migrate from a low risk area to a high risk area, such as the new commonwealth immigrants to England, \&? 
remain at low risk of developing MS and are therefore apparently immune to the disease. This suggests that MS is probably caused by a virus infection.

Other possible causes have been considered, such as a high consumption of milk (Swank, 1961) but this does not fit well the pattern of the disease. Milk products are consumed in large quantities by White South Africans.

How do the very small number of Asian, African, and West Indian immigrants who do develop MS differ genetically and environmentally from the other immigrants? It would be of interest to see if their genetic make-up, for instance HLA blood groups, and their background environment differ markedly from the other immigrants from their countries who do not develop MS.

The standard of hygiene in childhood could well be the deciding factor. In areas of good hygiene MS is common and in areas of poor hygiene it is rare. Asian and African immigrants to England and Wales, and their children who are born in England and Wales, may well provide an important clue to the aetiology of MS - the most important disease of the nervous system to affect those in the prime of life in Europe and North America.

We would like to thank the staff of the West Midland Regional Health Authority, in particular Sir Melville Arnott and Dr C. W. Gordon, for their assistance with this study, and the Metropolitan Regional Hospital Boards. Our thanks are also due to the medical records staff of the various hospitals and the neurologists who allowed us access to the patients' records. We are particularly indebted to the general practitioners, the family practitioner committees, the National Health Service register, Southport, and the staff of the Office of Population Censuses and Surveys. The Medico-Social Research Board of Ireland provided facilities for the study.

This study was supported by a research grant from the Multiple Sclerosis Society of Great Britain and Northern Ireland.

Reprints from: Geoffrey Dean, Director, MedicoSocial Research Board, Dublin 2.

\section{References}

Dean, G. (1967a). Annual incidence, prevalence and mortality of multiple sclerosis in white South Africanborn and in white immigrants to South Africa. British Medical Journal, 2, 724-730.

Dean, G. (1967b). Poliomyelitis among white immigrants to South Africa. South African Medical Journal, 41, Part I, 294-297.

Dean, G., and Kurtzke, J. F. (1971). On the risk of multiple sclerosis according to age at immigration to South Africa. British Medical Journal, 3, 725-729.

Dean, G., McLoughlin, H., Brady, R., Adelstein, A. M., and Tallett-Williams, J. (1976). Multiple sclerosis among immigrants in Greater London. British Medical Journal, 1, 861-864.

Lancet (1977). Editorial: Amyotrophic lateral sclerosis. Lancet, 1, 582.

Leibowitz, U., and Alter, M. (1973). Multiple Sclerosis: Clues to its Cause. North Holland: Amsterdam.

Office of Population Censuses and Surveys (1975). Population Trends No. 2. HMSO: London.

Poskanzer, D. C., Schapira, K., and Miller, H. (1963). Multiple sclerosis and poliomyelitis. Lancet, 2, 917-921.

Swank, R. L. (1961). A Biochemical Basis of Multiple Sclerosis. Springfield: Illinois. 